ANKAD E-ISSN:2587-0491

\author{
Araştırma Makalesi/Research Article
}

\title{
Ben Sosyal Bilgiler Öğretmeni Olsaydım...: Ortaokul Öğrencilerinin Görüşleri
}

\author{
Nadire Emel AKHAN iD 1 Burcu KAYMAK iD 2
}

${ }^{1}$ Doç. Dr. Akdeniz Üniversitesi, Eğitim Fakültesi, Sosyal Bilgiler Eğitimi Anabilim Dalı, Antalya, Türkiye,
neakhan@akdeniz.edu.tr
${ }^{2}$ Doktora Öğrencisi, Akdeniz Üniversitesi, Eğitim Bilimleri Enstitüsü, burcukocabiyik1991@gmail.com

Anahtar Kelimeler

Sosyal bilgiler öğretmeni, tutum, öğrenci görüşleri, sosyal bilgiler dersi..

\section{Keywords}

Social studies teacher, attitude, student views, social studies lesson.

\section{Sorumlu yazar/Corresponding Author}

Nadire Emel Akhan, Doç. Dr. Akdeniz Üniversitesi, Eğitim Fakültesi, Sosyal Bilgiler Eğitimi Anabilim Dalı, Antalya, Türkiye.

Email: neakhan@akdeniz.edu.tr

Geliş/Received: 15.07 .2020

Kabul/Accepted: 11.09 .2020
$\mathrm{Bu}$ çalışmanın amacı ortaokul 5., 6. ve 7 . sınıf öğrencilerinin sosyal bilgiler dersine ve sosyal bilgiler öğretmenlerine yönelik görüşlerini ortaya koymaktır. Nitel araştırma yöntemi ile hazırlanan bu çalışmanın verileri, 2018-2019 eğitim öğretim yılında Antalya'da bulunan bir devlet okulunda toplanmıştır. Çalışmaya 5. sınıftan 32, 6 . sinıftan 35, 7. sınıftan 33 olmak üzere toplam (49 kadın, 51 erkek) $\quad 100$ öğrenci katılmıştır. Verilerinin çözümlenmesinde betimsel analizden yararlanılmıştır. Genel olarak araştırmanın sonuçlarına bakıldığında, öğrenciye yönelik tutum, dersin işlenişine ve derste kullanılacak ögretim yöntem ve tekniklerine yönelik görüşlerde bulunulduğu belirlenmiştir. Sosyal bilgiler dersinin eğlenceli olarak, oyunlarla, farklı yöntem ve tekniklerden faydalanarak işlenmesi gerektiği belirtilmiştir. Ayrıca dikkat çekici olarak sosyal bilgiler dersinin sevdirilmeye ihtiyacı olan bir ders olarak belirtildiği, sosyal bilgiler öğretmeni olsalar öncelikle dersi sevdirmeye çalışacaklarını ifade ettikleri belirlenmiştir. $\mathrm{Bu}$ sebeple sosyal bilgiler öğretmenleri tarafından öğrencilerden dersle ve kendileri ile ilgili düzenli dönütler alarak dersin niteliğini arttırmaya çalışmaları, derste farklı öğretim tekniklerini kullanmaya önem vermeleri önerilmektedir.

\section{If I Was a Social Studies Teacher...: Views of Secondary School Students}

\begin{abstract}
The main purpose of this study is to identify the views of secondary school students (5th, 6th, and 7th) on the social studies course and social studies teachers. A qualitative methodology has been utilized to explore the views of secondary school students. The sample consists of 100 students in total (49 female, 51 male). 32 participants were $5^{\text {th }}$ grade students, 35 were $6^{\text {th }}$ grade students and 33 were $7^{\text {th }}$ grade students who were studying 2018-2019 fall semester at a state school in Antalya/Turkey. The data were analyzed through descriptive analysis. The study has revealed that the views of secondary school students focus on the teacher attitudes towards students and course methodology. They have suggested that the course can be taught through games and using different techniques and methodology. Besides, they have noted that the social studies course is the only one that needs to be more
\end{abstract}

\section{Önerilen Atıf / Suggested Citation:}

Akhan, N.E. \& Kaymak, B. (2020). Ben Sosyal Bilgiler Öğretmeni Olsaydım... : Ortaokul Öğrencilerinin Görüşleri, Anadolu Kültürel Araştırmalar Dergisi, 4(3), 264-277 
attractive. "If they were a social studies teacher, they would primarily make the course more loveable and popular." Gearing up the quality of the course through regular feedbacks from the students on the course and course teachers and using varied teaching methodology are recommended for social studies teachers.

\section{GíRiş}

Sosyal bilgiler; arkeoloji, ekonomi, coğrafya, tarih, hukuk, felsefe, siyaset bilimi, din, sosyoloji, psikoloji gibi farklı disiplinleri koordine ederek sistematik bir çalışma bütünlügü içerisinde kendine uygun içerikleri sağlamaktadır. Bu koordineli alanın temel amaçları incelendiğinde, birbirine bağımlı bir dünyada kültürel çeşitliliği olan, demokratik bir toplumun vatandaşları olarak gençlerin kamu yararına uygun şekilde bilinçli ve gerekçeli kararlar almalarını hedeflediği görülmektedir. Bununla birlikte vatandaşlık yeterliğini teşvik ederek öğrencinin kamusal yaşama aktif olarak dahil olabilmeleri için gerekli bilgi, beceri, entelektüel süreç ve demokratik eğilimlere sahip olmasını da amaçlamaktadır (NCSS, 1994; Ross, 2006; McLemore, 1976; Zevin, 2009).

Sosyal bilgiler dersinin amaçları doğrultusunda, etkili bir sosyal bilgiler öğretiminin sağlanabilmesi için birçok faktörün bulunduğu görülmektedir. Şüphesiz bu faktörlerden birisi ise sosyal bilgiler öğretmenleridir. Sınıf içerisinde öğretmenin öğrenciye karşı tutumu, öğrencinin derse karşı ilgisini, motivasyonunu ve öğrenme düzeyini etkilemektedir. Öğretmenin derste kullandığ 1 üslup, benimsemiş olduğu ödül ve cezalara yönelik tutumları, mesleki yeterlilikleri, kişisel nitelikleri, sergilemiş olduğu davranışlar dersin öğrenme çıktıları noktasında kritik bir öneme sahiptir. Tüm bu faktörler öğrencinin sosyal bilgiler dersine karş1 tutumunu etkilemesinin yanı sira bu doğrultuda özgüvenlerini de etkileyebilmektedir (Petty, Good ve Handler, 2016; Dilekmen, 2008; Gültekin, 2015; Shivakumar ve Manichander, 2013; Kyle, 2011; Oliver ve Reschly, 2007; Sezer, 2018). Bu sebeple bu noktalar göz önünde bulundurulduğunda sosyal bilgiler derslerinde öğretmenlerin birincil yapılandırma rolü oynadığı unutulmamalıdır (Ross, 2006; David ve Vera, 2017). Çünkü öğretmenin sahip olduğu yeterlilikler ve nitelikler, kendini geliştirme durumları, devam eden mesleki gelişim durumları öğrencinin ilgi, beklenti, yetenek ve anlama becerileri üzerinde doğrudan etkilidir (Gonser, 2018; Sezer, 2018).

Sosyal bilgiler dersi sıklıkla "sıkıcı, zorlayıcı, ilgi çekici olmayan" şeklinde tanımlanmaktadır (Heafner, 2004). Bu noktada sosyal bilgiler öğretmenlerinin belirlenen müfredattan daha fazlasını yapmaları gerekmektedir. Çünkü zaman zaman belirlenmiş resmi müfredat ile öğrencinin gerçek yaşamında deneyimlediği müfredat arasında farklılıklar oluşabilmektedir. Ayrıca müfredatın uygulanma aşamasında yapılan planlamalar ve uygulanan öğretim stratejileri de yasal müfredata ek olarak öğretmen ve öğrenci arasındaki günlük etkileşimi ve öğrencinin derse yönelik bakış açısını etkilemektedir. Bu sebeple öğretmenlerin sosyal bilgiler dersinde uygulanan müfredatın çıktılarından daha iyi bir verim alınmasını sağlayacak kilit noktalardan birini oluşturduğu söylenebilmektedir. Çünkü sosyal bilgiler öğretmeni gerek okul içinde gerekse okul dışındaki olaylardan yararlanarak öğrenciyi gerçek hayat problemleri ile karşılaştırılmalı, öğrencinin günlük hayatta karşılaştıkları sosyal problemler üzerine yansıtıcı olarak düşünmelerini sağlamalıdır. Böylelikle öğrencilerinin derse yönelik tutumları, dersi sevme durumları ve dersten aldıkları verim doğru orantılı olarak etkilenecektir (Heafner, 2004; Ross, 2006; MEB, 2018).

Etkili bir sosyal bilgiler öğretiminin sağlanması noktasında önemli faktörlerden biri de derste kullanılan öğretim yöntem ve teknikleridir. Derste kullanılabilecek tek bir yöntem bulunmamakla birlikte bu yöntem ve teknikler çeşitli faktörlere göre değişiklik göstermektedir. Kullanılacak yöntem ve tekniğin etkisi, öğrencinin özelliğine, konuya, kazandırılmak istenen 
hedeflere ve öğretmene göre değişmektedir. Bir sosyal bilgiler öğretmeni derste çeşitli öğretim yöntem ve teknikleri kullanılabilmektedir. Gezi gözlem, anlatım, tartışma, örnek olay, drama/rol yapma, problem çözme, grup çalışması, laboratuvar yöntemi, simülasyon, iş birliğine dayalı öğretim, soru-cevap, çoklu zeka, beyin firtınası gibi teknikler bunlardan bazılarıdır. Belirtilen kriterler de dikkate alınarak öğretmenin derste kullanacağı yöntem ve teknikleri iyi bilip, en uygun olanı seçmesi gerekmektedir (Heafner, 2004; Çelikkaya, 2013; Akbaba, 2015; Çelikkaya ve Kuş, 2009; Kan, 2006; Sivakumar, 2018). Ayrıca öğrencilere dersi sevdirecek hikaye, tarihi roman, hatıra, gezi yazısı, fikra gibi edebi ürünlerden, mimari, heykel, sinema, resim, musiki, müzik, dans minyatür gibi geleneksel ve modern sanat eserlerinden de yararlanılabilmektedir (MEB,2018; McDonald ve Fisher, 2006).

Sosyal bilgiler dersinde kullanılan materyallerin öğretimde önemli yeri bulunmaktadır. Öğretmenin sosyal bilgiler dersinde kullandığı malzemeler, kaynak kitaplar, derste yaptırdığ etkinlikler, öğretmenin teknik bilgi ve birikimi, tüm bunları bir araya getirerek uygulamaya koyma durumları öğrencilerin sosyal bilgiler dersine yönelik tutumunu etkileyen belli başlı etkenler arasında yer almaktadır. Dersle ilgili, etkili sosyal bilgiler öğretimine yönelik materyallerin kullanılması öğrencinin derse yönelik olumsuz bakış açısının kırılmasına yardımcı olmaktadır. Çünkü materyal ilgi çekici bir unsur görevi görmesinin yanı sıra öğretmenin ve öğretme sürecinin vazgeçilmez faktörlerindendir. Dikkatli ve özenle seçilerek kullanılan öğretim materyalleri derste verilmek istenen mesajın daha kolay ve daha açık bir şekilde yayılmasını sağlamaktadır. Bu noktada seçilen materyallerin yaş düzeyine göre özenle seçilerek kullanılması da oldukça önemlidir. Öyle ki, bu materyallerin sosyal bilgiler alanına uygun bir ortamda veya sosyal bilgiler laboratuvarında muhafaza edilmesi sosyal bilgiler dersinin materyallerinin tanınması ve erişiminin sağlanabilmesinde dersin verimliliği bakımından oldukça önemli olacaktır. Çünkü öğrenme duygusu ne kadar farklı duyu organına hitap ederse, ögrenme de o denli etkili olmaktadır. Bu sebeple sosyal bilgiler dersinde materyal seçimine özen gösterilerek, bunların kullanımına önem verilmesi gerekmektedir (Heafner, 2004; David \& Vera, 2017; Akhan ve Kaymak, 2019-2020; David \& Vera, 2017).

Sınıf içerisinde birden fazla uyarıcı olabilir ancak öğrenci bu uyarıcılardan birkaçını algılayabilmektedir. Çünkü öğrenciler seçici ve gönüllü olarak bir kontrolün öznesi durumundadır (İnel ve Çetin, 2017). Bunun yanı sıra görev deneyimi de motivasyonu etkileyen faktörlerdendir. Oysaki etkili öğrenme, öğrencilere tanınan uygun öğrenme ortamlarında, motivasyonu yüksek öğrencilerle sağlanmaktadır (Sezer, 2018). Bazı teorisyenlere göre, öğrencilerin aktif manipülasyonu öğrenmeyi olumlu düzeyde etkilemektedir. Bir öğrencinin görevden kaçınması veya göreve yaklaşmasında etkili olan anahtar faktör öğrencilerin o görevi önemli olarak atfetme durumlarına bağlıdır. Örneğin basitleştirilmiş içerikler, sıradan görevler öğrencinin derse ilgisini azaltabilir. Çünkü öğrencilerin eğlenceli olduğunu düşündükleri görevlere yaklaşarak bu görevlere karşı motivasyonlarının artma eğilimi vardır. Öte yandan öğrenciler genellikle karmaşık, yorumlama gerektiren, tartışılması istenilen konularda da başarısız olmaktadır. Bu sebeple tüm bu noktalar göz önünde bulundurulduğunda öğrencinin sürece dahil olduğu, aktif olarak öğretime katılım sağladığı, projeler yaparak derste aktif olduğu öğretim ortamlarında bulunmaları, motivasyonları üzerinde etkili olmaktadır (Blumenfeld, Mergendoller \& Swarthout, 1987; Kincheloe, 2001; Eccles \& Wigfield, 2002).

Bir diğer etken ise, öğrencinin dersi sevme durumudur. Öğrenciler sosyal bilgiler dersinin değerli olduğunu, daha da önemlisi sosyal bilgilerin bir parçası olduklarını hissetmeleri gerekmektedir. Bu hissin oluşmaması, bir nevi sivil okuryazarlığın düşük seviyede olduğunu buna bağlı olarak da halkın sosyal bilgiler eğitimine olan güvenin düşük seviyede seyrettiğini göstermektedir. Bu da, sosyal bilgiler dersinin öğrenciler tarafindan sevilmemesini veya daha az tercih edilebilir olmasının sebepleri arasında gösterilebilmektedir. Sosyal bilgilerin 
faydalarının, öğrencilerin de bu dersin bir parçası olduklarının bilincinde olmaları, en az diğer dersler kadar önemli olduğunun farkedilmesi, dersin hedeflerine ulaşılması noktasında önemli etkenlerden birini oluşturmaktadır (Schug, Todd \& Beery, 1982).

Alan yazın incelendiğinde ideal-etkili öğretmen, derse karşı tutum, etkili öğretim, ideal ders kitabı ile ilgili çalışmaların (Yurdakal, 2019; Çakar ve Öner, 2007; Çetin, 2001; Aktepe, Tahiroğlu ve Meydan, 2014; Kan, 2006; Cülha, Ateş ve Nazlı, 2018; Gömleksiz ve Kan, 2013; Demir ve Akengin, 2010; Gündüz, 2014; Gençtürk, Akbaş ve Kaymakçı, 2012; Aktepe, Tahiroğlu ve Meydan, 2014) yer aldığı görülmektedir. Bu çalışmalarda, genellikle tek bir problem üzerine odaklanılarak genel bir değerlendirme yapılmaktadır. Bu nedenle, sorunun tam olarak saptanamadığ 1 söylenebilmektedir. Bu çalışmada ise doğrudan öğrencinin kendini sosyal bilgiler öğretmeni yerine koyması istenerek öğrencilerin görüşleri alınmaya çalışılmıştır. Böylece öğrencilerin sosyal bilgiler öğretmenlerini göz önünde bulundurarak, bir günlüğüne sosyal bilgiler öğretmeni olmaları halinde neler yapıp yapmayacakları, sosyal bilgiler dersi için öğretmenlerinin kendilerine nasıl davranmalarını istedikleri, dersi nasıl işleyerek hangi yöntem ve teknikleri kullanmalarını bekledikleri ve sosyal bilgiler dersine karşı tutumlarının ortaya konulması amaçlanmaktadır.

\section{YÖNTEM}

$\mathrm{Bu}$ çalışmada öğrencilerin sosyal bilgiler öğretmenine ve sosyal bilgiler dersine yönelik görüşlerini belirlemek amaciyla "var olan bir durumu, var olduğu şekliyle betimlemeyi amaçlayan" (Karasar, 2006) betimsel modelde tasarlanan nitel bir araştırmadır.

\section{1.Çalışma Grubu}

Araştırmanın çalışma grubunu, 2018-2019 eğitim-öğretim yılı döneminde Milli Eğitim Bakanlığı'na bağlı kolay ulaşılabilir örneklem yoluyla seçilen bir devlet okulunda okuyan, 5 . sinıftan 32, 6. sinıftan 35, 7. sinıftan 33 olmak üzere toplam (49 kadın, 51 erkek) 100 öğrenci oluşturmaktadır. Araştırmaya, belirlenen devlet okulunda ki 5.,6. ve 7. sinıflarında okuyan tüm sınıflar dahil edilmiştir. 4. sınıfların sosyal bilgiler derslerine sosyal bilgiler öğretmenleri yerine sınıf öğretmenleri girdiği için çalışmanın amacına uygun olmayacağı gerekçesi ile bu sınıf düzeyi çalışmaya dahil edilmemiştir.

\subsection{Verilerin Toplanması ve Analizi}

Araştırmada veri toplama aracı olarak, alan uzmanlarının görüşleri doğrultusunda, Altıparmak, Aklar ve Dursun (2017)'un çalışmasında kullanmış olduğu sorular sosyal bilgiler alanına uyarlanarak kullanılmış ve öğrencilere "Bir günlüğüne sosyal bilgiler öğretmeni olsaydım .......yapardım/...........yapmazdım" şeklinde bir metin verilerek boş yerlerin doldurulması istenmiştir. Öğrencilerin düşüncelerini etkilememek ve fikirlerini olduğu gibi yansıtmalarını sağlayabilmeleri için metin dişında herhangi bir müdahalede bulunulmayarak, araştırmacılar tarafından yorum yapılmamıştır. Öğrencilere verilen metni doldurmaları için herhangi bir zaman veya sayfa sınırlamasında bulunulmamıştır. Çalışmadan toplanan veriler ilgili literatür dikkate alınarak analiz edilmiştir. Verilerin çözümlenmesinde betimsel analizden yararlanılmıştır. Betimsel analizde elde edilen veriler önceden belirlenen temalara göre özetlenerek yorumlanmaktadır. Ayrıca betimsel analizde veriler temalara göre düzenlenebileceği gibi, gözlem ve görüşme süreçlerinde kullanılan soru veya boyutlar dikkate alınarak da sunulabilir (Yıldırım ve Şimşek, 2013). Araştırmada elde edilen verilerin çözümlenmesi, çalışmanın geçerlik ve güvenirliğini arttırması açısından araştırmacının dışında alanında uzman iki kişi ile gerçekleştirilmiştir. Miles ve Huberman'ın (1994) R(Güvenirlik) = [Na (Görüş Birliği) / Na (Görüş Birliği) + Nd (Görüş Ayrılığı)] x 100 formülü kullanılarak yapılan hesaplamaya göre güvenirlik \%84 bulunmuş ve araştırma güvenilir kabul edilmiştir. 
Ayrıca çalışmanın bulguları katılımcıların görüşlerinden yapılan doğrudan alıntılar (7Ö17: 7 . sınıf öğrenci 17, 5Ö6: 5. sınıf öğrenci 6 vb.) ile desteklenmiştir.

\section{BULGULAR VE YORUM}

\subsection{Ortaokul öğrencilerinin sosyal bilgiler öğretmeni olmaları halinde öğrencilere yönelik tutumlarına ilişkin bulguları}

Tablo 1. Öğrenciye yönelik tutuma ilişkin görüşler

\begin{tabular}{|c|c|c|}
\hline Görüşler & $\mathbf{f}$ & Yüzde (\%) \\
\hline Öğrencilerime kötü davranmam & 82 & 31,53 \\
\hline Yaramazlık yapanlara ceza veririm & 46 & 17,69 \\
\hline Öğrencilerime kızmam/bağırmam & 26 & 10 \\
\hline Ceza vermem & 23 & 8,84 \\
\hline Öğrencilerime iyi davranırım & 19 & 7,30 \\
\hline Yaramazlık yapmalarına izin vermem & 12 & 4,61 \\
\hline Yaramazlık yapanları uyarırım & 9 & 3,46 \\
\hline Ayrım yapmam & 7 & 2,69 \\
\hline Güler yüzlü olurum & 6 & 2,30 \\
\hline Öğrencilerime saygı duyarım & 5 & 1,92 \\
\hline Herkese söz hakkı veririm & 5 & 1,92 \\
\hline Sinirlenince ders anlatmamazlık yapmam & 4 & 1,53 \\
\hline Öğrencilerimin dertlerini dinlerim & 4 & 1,53 \\
\hline Öğrencilerimle arkadaş gibi davranırım & 3 & 1,15 \\
\hline Fazladan not vermem & 2 & 0,76 \\
\hline Öğrencimin ailesi ile irtibatta olurum & 2 & 0,76 \\
\hline Rehber öğretmenle iş birliği içinde olurum & 1 & 0,38 \\
\hline Dürüst olurum & 1 & 0,38 \\
\hline Soruları cevaplarım & 1 & 0,38 \\
\hline Özel yetenekli çocuklarla ilgilenirim & 1 & 0,38 \\
\hline Program hazırlarım & 1 & 0,38 \\
\hline Toplam & 260 & 100 \\
\hline
\end{tabular}

Tablo 1'de çalışmaya katılan öğrencilerin bir günlüğüne sosyal bilgiler öğretmeni olmaları halinde öğrencilere yönelik tutumlarına dair görüşlerine yer verilmiştir. Buna göre belirleyici yanıtların "öğrencilerime kötü davranmam $(\% 31,53)$ " ve "yaramazlık yapanlara ceza veririm $(\% 17,69)$ " şeklinde olduğu görülmektedir. Öte yandan, ceza yöntemine bakış açılarının olumsuz olan öğrencilerinin ise "ceza vermem $(\% 8,84)$ " şeklinde görüş bildirdikleri de görülmektedir. Bu yanıtları "öğrencilerime kızmam/bağırmam (\%10)", "öğrencilerime iyi davranırım $(\% 7,30)$ ", "yaramazlık yapanlara izin vermem $(\% 4,61)$ " gibi yanıtların takip ettiği belirlenmiştir. Bunların yanı sıra öğrencilerin sosyal bilgiler öğretmeni olmaları halinde, öğrencilerine iyi davranacağı, sesini yükseltmeyeceği ayrım yapmayacağı, adaletli olacağı, güler yüzlü davranacağı, öğrencilerine saygı duyacağı, fazladan not vermeyeceğini belirttikleri 
de söylenebilmektedir. Öğrencilerin verdikleri yanıtlara göre, öğretmenin öğrenciye yaklaşımının önemli olduğu, öğrenciye iyi davranılmasının önemsendiği ve bu doğrultuda öğretmenlerin bilgilendirilmesi gerektiği söylenebilmektedir. Öğrencilerin cevaplarından bazıları şu şekildedir:

“Çocuklara güler yüzlü davranırdım. Yaptığı hatalar da yanıma çağırıp onlarla ayrı olarak konuşurdum” (6Ö18).

"Öğrencilere çok iyi davranırdım, çünkü öğrenciler yeni nesilin öğretmenleridir" (5Ö28).

"Otizmli ve down sendromlu öğrencilerin ailesinin ikna edip, okula getirirdim. Çocuklara böyle sorunların ve böyle insanların engelli olmadığını anlatmak isterdim" (7Ö17).

"Saygılı dürüst davranırım. Öğrencilerimin beni arkadaşları gibi yakın hissetmesini sağlarım" (6Ö8).

\subsection{Ortaokul öğrencilerinin sosyal bilgiler öğretmeni olmaları halinde sosyal bilgiler dersini nasıl işleyeceklerine ilişkin görüşlerine yönelik bulgular}

Tablo 2. Dersin işlenişine yönelik görüşler

\begin{tabular}{|c|c|c|}
\hline Görüşler & $\mathbf{f}$ & $\begin{array}{l}\text { Yüzde } \\
(\%)\end{array}$ \\
\hline Dersi oyunla anlatırım & 73 & 24,74 \\
\hline Dersi eğlenceli anlatırım & 37 & 12,54 \\
\hline Dersi farklı etkinliklerle işlerim & 32 & 10,84 \\
\hline Konuya uygun müzikleri kullanırım & 26 & 8,81 \\
\hline Konuyla ilgili film izlettiririm & 24 & 8,13 \\
\hline Geziye götürürüm & 24 & 8,13 \\
\hline Soruyu doğru bilene ödül veririm & 13 & 4,40 \\
\hline Belli saatlerde kitap okuturum & 10 & 3,38 \\
\hline Not tuttururum & 10 & 3,38 \\
\hline Dersi resimlerle anlatırım & 8 & 2,71 \\
\hline Konuyla ilgili tiyatroya/sinemaya götürürüm & 7 & 2,37 \\
\hline Canlandırma yaptırırım & 4 & 1,35 \\
\hline Konuyu anlatırken bilmecelerden yararlanırım & 4 & 1,35 \\
\hline Dişarda ders işlerdim & 4 & 1,35 \\
\hline Oyun hamuruyla etkinlik yaptırırım & 2 & 0,67 \\
\hline Harita kullanırım & 2 & 0,67 \\
\hline Derste sözlü/yazılım anlatımın ikisini de kullanırım & 2 & 0,67 \\
\hline Satranç oynatırım & 2 & 0,67 \\
\hline Öğrenciye ders anlattırmam & 2 & 0,67 \\
\hline Jest ve mimiklerimi kullanırım & 2 & 0,67 \\
\hline Atatürk köşesini kullanırım & 1 & 0,33 \\
\hline Konuyla ilgili şiirleri kullanırım & 1 & 0,33 \\
\hline
\end{tabular}




\begin{tabular}{llc}
\hline Tarihi kitaplardan faydalanırım & 1 & 0,33 \\
\hline Karikatürlerden yararlanırım & 1 & 0,33 \\
\hline Çizim yaptırırım & 1 & 0,33 \\
\hline Farklı kaynaklar kullanırım & 1 & 0,33 \\
\hline Geri dönüşümü derse dahil ederim & 1 & 0,33 \\
\hline & Toplam & 295 \\
\hline
\end{tabular}

Tablo 2'de çalışmaya katılan öğrencilerin sosyal bilgiler öğretmeni olmaları halinde sosyal bilgiler dersinin işlenişine yönelik görüşlerinin ifade edildiği belirlenmiştir. Buna göre belirleyici yanıtların "dersi oyunla anlatırım (\%24,74)", "dersi eğlenceli anlatırım $(\% 12,54)$ " ve "dersi farkl1 etkinliklerle işlerim $(\% 10,84)$ " şeklinde olduğu görülmektedir. Bu cevapları ise "konuya uygun müzikleri kullanırım $(\% 8,81)$ ", "konuyla ilgili film izlettiririm $(\% 8,13)$ ", "geziye götürürüm $(\% 8,13)$ " gibi yanıtların takip ettiği belirlenmiştir. Bunların dışında öğrencilerin sosyal bilgiler öğretmeni olmaları halinde, derste başarılı olunması ya da soruların doğru bilinmesi durumunda öğrencilerine ödül verecekleri, konuyla ilgili tiyatro ve sinemaya götürebilecekleri, ders anlatımında canlandırma etkinliklerine önem verileceği, bilmecelerin ve haritaların kullanılacağı, oyun hamuruyla etkinlikler yapılmasına dikkat edileceği belirtilmiştir. Öğrencilerin verdikleri yanıtlara göre, öğrencilerin dersi eğlenceli hale getirecek aktivitelerle işlenmesine önem verdikleri ve bunun için farklı yöntemlerden yararlanılabileceğini düşündükleri, bu doğrultuda öğrencilerin dersin işlenişine yönelik fikirlerinin alınmasının faydalı olabileceği söylenebilmektedir. Öğrencilerin cevaplarından bazıları şu şekildedir:

"Onlara ormanda ders anlatırdım. Hayvanların nasıl yuva yaptığını, doğal afetleri anlatırdım. Onlara çocuğum gibi bakar dersi eğlenceli şekilde anlatırdım” (5Ö5).

“...Konuya uygun resim çizmelerini söyler ve özet çıkarmalarını isterdim” (7Ö21).

"Konuyu öğrencilere en iyi anladığı şekilde anlatırdım. Dersi oyunla ve filmlerle anlatırdım" (6Ö18).

"Mesela konumuz yer yüzü şekilleriyle oyun hamuruyla onlara ova, dağ, plato, yarımada gibi şeyler yaptırırdım” (5Ö28).

\subsection{Ortaokul öğrencilerinin öğretim yöntem ve tekniklerine ilişkin görüşlerine yönelik bulgular}

Tablo 3. Öğretim yöntem ve tekniklerine yönelik görüşler

\begin{tabular}{lll}
\hline Görüşler & $\mathbf{f}$ & Yüzde (\%) \\
\hline Test/ soru çözdürürüm & 32 & 38,09 \\
\hline Konu tekrarı yaparım & 25 & 29,76 \\
\hline Maket/modelleme yaptırırım & 7 & 8,33 \\
\hline Derste yarışmalar yaparım & 5 & 5,95 \\
\hline Proje yaptırırım & 3 & 3,57 \\
\hline Derste soru-cevap yaparım & 2 & 2,38 \\
\hline Örnekler verir, benzetmelerden yararlanırım & 2 & 2,38 \\
\hline
\end{tabular}




\begin{tabular}{|c|c|c|}
\hline Ev ödevi veririm & 2 & 2,38 \\
\hline Farklı yöntemlerle kullanırım & 1 & 1,19 \\
\hline Balık kılçı̆̆1 çizerim & 1 & 1,19 \\
\hline Münazara/tartışma yaparım & 1 & 1,19 \\
\hline Slaytlar hazırlarım & 1 & 1,19 \\
\hline Akıllı tahtayı kullanırım & 1 & 1,19 \\
\hline Bilgisayarı kullanırım & 1 & 1,19 \\
\hline Toplam & 84 & 100 \\
\hline
\end{tabular}

Tablo 3'te çalışmaya katılan öğrencilerin sosyal bilgiler öğretmeni olmaları halinde sosyal bilgiler dersinde kullanılacak öğretim yöntem ve tekniklerine yönelik görüşlerine yer verilmiştir. Buna göre belirleyici yanıtların "test/soru çözdürürdüm $(\% 38,09)$ " ve "konu tekrarı yaparım $(\% 29,76)$ " şeklinde olduğu görülmektedir. Bu yanıtları "maket/modelleme yaptırırım $(\% 8,33)$ ", "derste yarışmalar yaparım $(\% 5,95)$ ", proje yaptırırım $(\% 3,57)$ " gibi cevaplar takip etmektedir. Bunların yanı sıra öğrencilerin sosyal bilgiler öğretmeni olmaları halinde derste soru cevap yöntemini kullanacağı, konuya uygun örnekler verilerek bilgiyi somutlaştırmak için benzetmelerden yararlanacağı, ders anlatımında farklı yöntemlerin kullanılarak balık kılçı̆̆ı gibi modellerden yararlanacakları ifade edilmektedir. Öğrencilerin verdikleri cevaplara göre öğrencilerin ders işlenişinde farklı yöntem ve tekniklerin kullanılmasına önem verdikleri, işlenecek konuda kullanacak yöntemler konusunda öğrencilerin fikirlerinin alınmasına önem verilmesi gerektiği söylenebilmektedir. Öğrencilerin cevaplarından bazıları şu şekildedir:

"Öğrencilere arada sırada konuyu anlatmak için film izletip maket yaptırırdım, gezi düzenlerdim. Ama çok şımartmamaya çalışırdım” (6Ö22).

"Bir konu ortaya atıp bir tartışma konuşması yaptırırım onlara” (7Ö26).

"Platoyu, ovayı, beşeri özellikleri anlatır bunlarla ilgili balık kılçı̆̆ı çizerdim" (5Ö25).

\subsection{Ortaokul öğrencilerinin Sosyal bilgiler dersine karşı tutumlarına yönelik görüşlerine ilişkin bulgular}

Tablo 4. Sosyal bilgiler dersine yönelik tutumlarına ilişkin görüşler

\begin{tabular}{lll}
\hline Görüşler & $\mathbf{f}$ & Yüzde (\%) \\
\hline Sosyal bilgiler dersini sevdiririm/sevdirmeye çalışırım & 32 & 59,25 \\
\hline İyi bir sosyal bilgiler öğretmeni olurum & 7 & 12,96 \\
\hline Sosyal bilgiler dersini seviyorum & 5 & 9,25 \\
\hline Sınıf ortamı düzenlenmelidir & 4 & 7,40 \\
\hline Sosyal bilgiler çok sıkıcı bir ders & 2 & 3,70 \\
\hline Sosyal bilgiler dersinin faydalarını anlatırım & 1 & 1,85 \\
\hline Dersi sevsinler diye önce kendimi sevdiririm & 1 & 1,85 \\
\hline Bazı konular çok zor & 1 & 1,85 \\
\hline Ders saati yetersiz & 1 & 1,85 \\
\hline & Toplam & 54 \\
\hline
\end{tabular}


Tablo 4'te çalışmaya katılan öğrencilerin sosyal bilgiler dersine yönelik tutumlarına ilişkin görüşleri verilmiştir. Buna göre dikkat çekici şekilde belirleyici yanıtın "sosyal bilgiler dersini sevdiririm/sevdirmeye çalışırım $(\% 59,25)$ " cevab1 olduğu görülmektedir. Öğrencilerin genellikle sosyal bilgiler dersini sevmedikleri, öğretmen oldukları takdirde öğrencilerinin sosyal bilgiler dersine yönelik tutumlarını arttırmaya çalışacaklarını, yani dersi sevdirecekleri veya sevdirmeye çalışacakları söylenebilmektedir. Ayrıca bu yanıtları "iyi bir sosyal bilgiler öğretmeni olurum $(\% 12,96)$ ", "sınıf ortamını düzenlenmelidir $(7,40)$ ", "sosyal bilgiler dersinin faydalarını anlatırım $(1,85)$ ", "dersi sevsinler diye önce kendimi sevdiririm $(1,85)$ " şeklinde cevapların takip ettiği görülmektedir. Ayrıca bazı öğrencilerin olumsuz bakış açısına sahip olduğu; bazı konuları zor $(\% 1,85)$, sıkıcı $(3,70)$ şeklinde nitelendirerek dersi sevmediklerini de ifade ettikleri belirlenmiştir. Öğrencilerin verdikleri yanıtlara göre sosyal bilgiler dersini sevmenin önemli olduğu, bunun için de öğretmenin önemli bir faktör olduğu, sınıf ortamının iyileştirilmesi, dersin işlevselliği/faydaları konusunda da öğrencilerin bilinçlendirilmesi gerektiği söylenebilmektedir. Öğrencilerin cevaplarından bazıları şu şekildedir:

"Çocuklara iyi davranırdım. Onlara test verip onlarla birlikte soru çözerdik. Sosyal bilgileri daha iyi tanımalarını sağlar ve dersimi sevdirmeye çalışırdım” (6Ö17).

“...Sosyal bilgiler dersini sevdirmek için elimden geleni yapardım. Ama ders saati yetersiz geldiğinden ders saatimizin 5 saat olmasını isterdim. 4 saat ders işlemek ve 1 saatinde klasik müzik eşliğinde kitap okuturdum" (7Ö17).

Sosyal bilgiler dersinin faydalarını anlatırdım" (5Ö8).

"Dersi sıkıcı yapmam, çünkü ders sıkıcı olursa öğrenciler sosyal bilgiler dersinde sik1lırlar" (7Ö30).

Öğrencilerin sosyal bilgiler öğretmeni olmaları halinde ne yapacakları/yapmayacakları sorusu yöneltildiğinde en çok söylenen cevapların genel olarak Tablo 5'teki gibi olduğu belirlenmiştir.

Tablo 5. Öğrencilerin sosyal bilgiler öğretmeni olmaları durumunda ne yapacakları/yapmayacaklarına ilişkin en fazla söylenen yanıtlar

\begin{tabular}{ll}
\hline Görüşler & f \\
\hline Öğrencilerime kötü davranmam & 82 \\
\hline Dersi oyunla anlatırım & 73 \\
\hline Test/ soru çözdürürüm & 32 \\
\hline Sosyal bilgiler dersini sevdiririm/sevdirmeye çalı̧ıırım & 32 \\
\hline
\end{tabular}

Tablo 5'te öğrencilere sorulan sorular doğrultusunda genel olarak en fazla söylenen dört maddenin ortaya çıktı̆̆ 1 görülmektedir. Bunlardan en fazla söylenen maddenin öğrencilere yönelik davranış şekline ilişkin olduğudur. Öğrenciler genellikle sosyal bilgiler öğretmeni olsalar öğrencilere iyi davranacaklarını, onlara kötü davranmayacaklarını ifade etmiştir. $\mathrm{Bu}$ bulguyu, dersin işlenişs şekline yönelik olan dersi oyunla anlatacaklarına dair bulgu takip etmektedir. Burada öğrencilerin ikinci en önemli nokta olarak dersin işleniş şeklini önemsedikleri ve dersin işlenişinde oyun gibi eğlenceli öğretim yöntemini tercih ettikleri görülmektedir. Bu yanıtı ise, derste kullanılacak yöntem ve teknikler ile sosyal bilgiler dersine yönelik tutuma ilişkin cevaplar takip etmiştir. Öğrenciler derste soru çözümü gibi teknikleri sevdikleri ve önemsedikleri görülmekte, ayrıca sosyal bilgiler dersine yönelik tutum için dersin sevdirilmeye ihtiyaç duyulduğunu ifade ederek, kendilerinin öğretmen olmaları halinde öncelikle sosyal bilgiler dersini sevdirmeye çalışacaklarını belirttikleri görülmektedir. 


\section{SONUÇ, TARTIŞMA ve ÖNERILER}

Bu çalışmada, sosyal bilgiler dersi alan ortaokul öğrencilerine "bir günlüğüne sosyal bilgiler öğretmeni olsaydım...........yapardım/yapmazdım” ifadesinin yer aldığı sorular verilerek, öğrencilerin vermiş olduğu cevaplardan ulaşılan kategoriler doğrultusunda "öğrenciye yönelik tutum, dersin işlenişine yönelik görüşler, öğretim yöntem ve tekniklerine yönelik görüşler ve sosyal bilgiler dersine yönelik tutum"lara dair bilgi edinilmeye çalışılmıştır. Elde edilen verilerden ortaya çıkan kategoriler doğrultusunda öğrencilerin sosyal bilgiler dersine yönelik duygu, düşünce, istek ve beklentilerinin çeşitlilik gösterdiği belirlenmiştir. Bu doğrultuda araştırmanın sonuçları genel olarak değerlendirildiğinde; çalışmaya katılan öğrencilerin, öğrenciye yönelik tutum üzerinde durdukları ve özellikle öğrencilerine kötü davranmayıp onları cezalandırmayacaklarını ifade ettikleri görülmektedir. Öğrencilerin herhangi bir öğretim yöntem ve tekniklerine dair resmi bir ders almamalarına rağmen öğrencilik tecrübelerine dayanarak farklı öğretim yöntemleri ifadesinde bulunup, derslerini bu şekilde işleyebileceklerini belirtmişlerdir. Öğrenciler derslerini test çözdürerek, konu tekrarı veya maket/modellemeler yaptırarak işleyeceklerini ifade etmişlerdir. Bu da derslerine giren farklı branşların öğretmenlerini iyi bir şekilde gözlemleyip, analiz ederek çıkarımlarda bulunabildiklerini gösterebilmektedir. Benzer şekilde dersin işlenişine yönelik ifade ettikleri alternatif ögretim aktiviteleri ve uygulamaları için de derslerini oyunla, eğlenceli bir şekilde, farklı etkinliklerden yararlanarak işleyeceklerini belirtmeleri, öğrenci gözünden nasıl daha iyi öğretim sağlanabileceğinin örneklerini oluşturabilmesi bakımından önemlidir. Ayrıca öğrencilerin sosyal bilgiler dersine yönelik tutumlara dair görüşlerine bakıldığında ise, dikkat çekici olarak sosyal bilgiler dersini sevdirmeye çalışacakları/sevdirecekleri cevabının verildiği görülmektedir. Bu yanıt sosyal bilgiler dersinin öğrenciler tarafindan az sevildiğini ve dersin sevdirilmeye ihtiyacı olduğunu göstermekle birlikte öte yandan kendilerinin sosyal bilgiler dersini sevdikleri için öğrencilerine de sosyal bilgiler dersini sevdirmeye çalışacaklarını göstermektedir. $\mathrm{Bu}$ noktada sosyal bilgiler öğretmenlerine önemli görevler düştüğü ifade edilebilmektedir.

Çalışmada elde edilen sonuçlara göre ilk olarak; öğrencilerin sosyal bilgiler öğretmeni olsalar öğrencilerine kötü davranmayacakları, onları cezalandırmayacakları, iyi davranacakları ve ders içindeki düzeni sağlayacaklarını ifade ettikleri belirlenmiştir. Bununla birlikte öğrencilerine saygılı, güler yüzlü, adaletli davranıp, bireysel farklılıklarına duyarlı olarak öğrencilerine arkadaşça davranacaklarını ifade etmiş̧lerdir. Çalışmanın bulgularına benzer olarak Çelikten ve Can (2003), Gökçe (2002), Gençtürk, Akbaş ve Kaymakçı (2012), Başaran ve Baysal (2016), Gündüz (2014), Evans (2002), Moreira (2002), Hebert (2002), Cülha, Ateş ve Nazlı (2018)'nın çalışmalarında öğrenciler arasında ayrım yapılmaması, iyi ve adaletli davranılarak ders içinde düzenin sağlanması gerektiği belirlenmiştir. Chan (2011), Gençtürk, Akbaş ve Kaymakçı (2012), Gültekin (2015), Eret (2013), Telli, Brok ve Çakıroğlu (2008)'nun çalışmalarında bireysel farklılıklara saygılı ve duyarlı olma, güler yüzlü olma ifadelerinin belirtildiği görülmektedir. Ayrıca Greimel-Uhrmann \& Geyer'in (2003)'ın çalışmasında ise “öğrencilere arkadaşça davranmaya önem verme" bulgusunun da çalışmanın bulgularıyla paralellik gösterdiği görülmektedir.

Dersin işlenişine yönelik görüşlere bakıldığında; dersin genellikle oyunla, eğlenceli bir şekilde ve konuya uygun etkinliklerle işlenmesinin önemsendiği belirlenmiştir. Sosyal bilgiler dersinde müzik, bilmece ve haritalardan yararlanılarak konuların işlenmesi, sinema, film, tiyatro ve gezi faaliyetlerine önem verilerek sosyal bilgiler dersinin işlenme aşamalarında bu faaliyetlerden yararlanılacağı da belirtilmiştir. Çalışmanın bulgularına paralel olarak Aktepe, Tahiroğlu ve Meydan (2014)'ın çalışmasında öğrencilerin gezilere götürülüp, derste haritalardan yararlanılmasının önemsendiği belirtilmiştir. Gökçe (2002), Gençtürk, Akbaş ve Kaymakçı 
(2012), Nicholas \& Williams (2010), Evans (2002) ve Gültekin (2015)'nin çalışmalarında öğrencilerin dersi oyunla veya eğlenceli bir şekilde işlenmesinin istenildiği belirtilmiştir. Ayrıca Kan (2006)'ın çalışmasında ise derste filmlerin kullanılabileceği bulgusu, çalışmanın bulgusu ile paralellik göstermektedir.

Çalışmada sosyal bilgiler dersinde kullanılabilecek öğretim yöntem ve tekniklerine dair görüşlere bakıldığında; öğrencilerin derste test ve sorular çözdürerek, konu tekrarı yapılmasına önem verdikleri görülmektedir. Ayrıca öğrenciler derste örnek maket/modellemeler ve projeler yaptıracaklarını belirterek, motivasyonu arttırması ve ilgiyi canlı tutması bakımından yarışmaların yapılmasının, farklı yöntem ve tekniklerin kullanılıp, konuyu somutlaştırması bakımından benzetme ve örneklerden yararlanılmasının da önemli olduğunu ifade etmişlerdir. Çalışmanın bulgusuna paralel olarak Gültekin (2015)'in çalışmasında dersteki başarıyı arttırmak adına derslerde konu tekrarı yapılmasının önemli olduğu belirlenmiştir. Mızrak Karcı (2016)'nın çalışmasında ise motivasyonu arttırmak, başarıyı değerlendirmek amacıyla derslerde farklı projelerden yararlanılarak öğrencilere projeler yaptırılması gerektiği ifade edilmiştir. Çetin (2001)'in çalışmasında ise dersin işlenişinde farklı yöntem ve tekniklerden yararlanılarak dersin işlenmesi gerektiği belirlenmiştir. Çalışmada sosyal bilgiler dersine yönelik tutumların belirlenmesine ilişkin görüşlere bakıldığında; sosyal bilgiler dersinin genellikle sevilmediği, zor ve sıkıcı bir ders olarak nitelendirildiği belirlenmiştir. Ayrıca dikkat çekici olarak öğretmeninin, sosyal bilgiler dersini sevmekte önemli bir faktör olduğu, öğrencilerin dersi sevmesi için öncelikle kendilerini sevdirmeye çalışacaklarını ifade ettikleri belirlenmiştir. Çalışmanın bulgularına paralel olarak Murphy, Delli ve Edwards (2004), Gültekin (2015), Moreira (2002), Schug, Todd ve Beery (1982), Nicholas ve Williams (2010), Evans (2002)'ın çalışmalarında dersin sıkıcı olarak görüldüğü için eğlenceli hale getirilmesinin ve dersin öğrenciye sevdirilmeye çalışılmasının gerektiği belirtilmiştir. Ayrıca Gültekin (2015), Başaran ve Baysal (2016)'ın çalışmalarında ise öğretmenin dersi sevdirmesi için öncelikle kendisini sevdirmesi gerektiği belirlenmiştir.

Çalışmada elde edilen sonuçlar 1şığında; sosyal bilgiler öğretmenlerinin öğrencilere kendilerini değerlendirmeleri için firsat vermeleri ve bu değerlendirmelere açı olmaları beklenmektedir. Bu sebeple öğretmenlerin, düzenli olarak öğrencilerinin kendileri ve derse yönelik görüşlerine dair fikirlerini almaları ve bu doğrultuda derslerini planlamaları faydalı olacaktır. Dersin işlenişi, derste uygulanacak aktiviteler, kullanılacak yöntemler hakkında öğrencilerin fikirlerinin alınması dersin başarısını etkileyeceği, öğrencinin derste söz hakkı olduğunu göstermesi bakımından da önemli olduğu düşünülmektedir. Ayrıca öğrencilerin kendilerini sosyal bilgiler öğretmeni yerine koyarak duygu ve düşüncelerini araştıran çalışmaya rastlanmamıştır. $\mathrm{Bu}$ sebeple elde edilen bulguların önem taşıdığı ve bu yönde çalışmaların yapılarak öğretmenlerin bilgilendirilmesinin faydalı olacağı düşünülmektedir.

\section{KAYNAKÇA}

Akbaba, B. (2015). Sosyal bilgiler ögretiminde görsel materyallerin kullanımı. İçinde M. Safran (Ed.), Sosyal bilgiler öğretimi (4. bask1), s.283-319. Ankara: Pegem Akademi.

Akhan, N. E. \& Kaymak, B. (2019). Sosyal bilgiler öğretmen adaylarının fakültelerindeki öğrenme ortamlarına yönelik görüşleri. Journal of History School, 43, 1503-1534.

Akhan, N. E. \& Kaymak B. (2020). The views of secondary school students toward social studies learning environments as a social studies laboratory. HAYEF: Journal of Education, 17(1), 121-149. 
Aktepe, V., Tahiroğlu, M. \& Meydan, A. (2014). Öğrencilere göre etkili bir sosyal bilgiler öğretimi için sınıf öğretmenlerinden beklentiler. Researcher: Social Science Studies, 2 (2), 1-11.

Altıparmak, K., Aklar, M.A. \& Dursun, G. (2017). Bir günlüğüne matematik öğretmeni olsaydım neler yapardım/yapmazdım? : öğrenci görüşleri. YYÜ Eğitim Fakültesi Dergisi, 14 (1), 1117-1140.

Başaran, A. R. \& Baysal, S. (2016). Öğretmen adaylarının ideal bir öğretmen hakkındaki görüşleri. İçinde Ö. Demirel \& S. Dinçer (Ed.), Eğitim Bilimlerinde Yenilikler ve Nitelik Arayış1 (1. bs, ss. 29-44). Ankara: Pegem Akademi Yayıncılık.

Blumenfeld, P. C., Mergendollar, J., \& Swarthout, D. (1987). Task as a heuristic for understanding student learning and motivation. Journal of Curriculum Studies, 19(2), 135- 148 .

Chan, W. K. (2011). Preservice teacher education students' epistemological beliefs and conceptions about learning. Instructional Science, 39(1), 87-108.

Cülha, A., Ateş, R. \& Nazlı, K. (2018). Özel yetenekli öğrencilerin ideal öğretmene ilişkin metaforlar1. Harran Education Journal, 3 (1), 39-51.

Çakar, Ö. \& Öner, Ü. (2007). Etkili bir sosyal bilgiler ögrretimi için öğrenci gözüyle ögretmenden beklentiler. Ulusal Eğitim Bilimleri Kongresi, Gaziosmanpaşa Üniversitesi, 5-7 Eylül Tokat.

Çelikkaya, T. (2013). Sosyal bilgiler öğretmenlerinin öğretim araç-gereç ve materyallerini kullanma düzeyleri. On dokuz Mayıs Üniversitesi Eğitim Fakültesi Dergisi, 32 (1), 73 105 .

Çelikkaya, T. \& Kuş, Z. (2009). Sosyal bilgiler öğretmenlerinin kullandıkları yöntem ve teknikler. Uludağ Üniversiesi Eğitim Fakültesi Dergisi, 22 (2), 741-758.

Çelikten, M. \& Can, N. (2013). Yönetici, öğretmen ve veli gözüyle ideal öğretmen. Selçuk Üniversitesi, Eğitim Fakültesi Dergisi, 15, 253-267.

Çetin, Ş. (2001). İdeal öğretmen üzerine bir araştırma. Millî Ĕ̆itim Dergisi, 149. https://dhgm.meb.gov.tr/yayimlar/dergiler/Milli_Egitim_Dergisi/149/cetin.htm adresinden 11.05.2020 de alınmıştır.

David, E. S. \& Vera, E. N. (2017). Social studies teaching resources in the 21st century. International Journal of Sociology and Anthropology Research, 3 (4), 8-14.

Demir, S. B. \& Akengin, H. (2010). Sosyal bilgiler dersine yönelik bir tutum ölçeğinin geliştirilmesi: geçerlik ve güvenirlik çalışması. E-Uluslararası Eğitim Araştırmaları Dergisi, 1 (1), 26-40.

Dilekmen, M. (2008). Etkili eğitim için etkili öğretmenlik. Atatürk Üniversitesi Sosyal Bilimler Enstitüsü Dergisi, 12(2), 213-221.

Eccles, J. \& Wigfield, A. (2002). Motivational beliefs, values, and goals. Annual Review of Psychology, 53, 109-133.

Eret, E. (2013). An assessment of pre-service teacher education in terms of preparing teacher candidates for teaching. Unpublishen Doctoral Thesis, The Department of Educatinal Sciences, Middle East Technical University, Ankara. 
Evans, J. F. (2002). Effective teachers: An investigation from the perspective of elementary school students. Action in Teacher Education, 24(3), 51-62.

Gençtürk, E., Akbaş, E., \& Kaymakçı, S. (2012). Qualifications of an ideal teacher according to social studies preservice teachers. Educational Sciences: Theory \& Practice, 12(2), 1569-1572.

Gonser, S. (2018). How social studies can help young students make sense of the world. https://chalkbeat.org/posts/ny/2018/07/12/how-social-studies-can-help-young-studentsmake-sense-of-the-world/ adresinden 01.04.2020 de alınmıştır.

Gökçe, E. (2002). İlköğretim öğrencilerinin görüşlerine göre öğretmenlerin etkililiği. Ankara Üniversitesi Ĕ̈itim Bilimleri Fakültesi Dergisi, 35(1-2), 1-9.

Gömleksiz, M. N. \& Kan, A. Ü. (2013). Sosyal bilgiler dersi tutum ölçeğinin geçerlik ve güvenirlik çalışması. Fırat Üniversitesi Sosyal Bilimler Dergisi, 23(2),139-148.

Greimel-Fuhrmann, B. \& Geyer, A. (2003). Students evaluation of teachers and instructional quality analysis of relevant factors based on empirical evaluation research. Assessment and Evaluation in Higher Education, 28(3),229-238.

Gültekin, M. (2015). İlköğretim öğrencilerinin ideal öğretmen algısı. Turkish Studies, 10 (11), 725-756.

Gündüz, M. (2018). İlkokul öğrencilerinin etkili öğretmen hakkındaki düşünceleri. YYÜ Eğitim Fakültesi Dergisi, 11 (1), 114-128.

Heafner, T. (2004). Using technology to motivate students to learn social studies. Contemporary Issues in Technology and Teacher Education, 4(1), 42-53.

Hebert, S.B. (2002). Expectations and experiences: case studies of four first-year teachers. LSU Doctoral Dissertations. 3113. https://digitalcommons.lsu.edu/cgi/viewcontent.cgi?article=4112\&context=gradschool dissertations adresinden 07.05.2020 de alınmıştır.

Kan, Ç. (2006). Etkili sosyal bilgiler arayışı. Kastamonu Ĕ̆itim Dergisi, 14 (2), 537-544.

Karasar, N. (2006). Bilimsel araştırma yöntemi. Ankara: Nobel Yayın Dağıtım.

Kincheloe, J. L. (2001). Getting beyond the facts: teaching social studies/social sciences in the twenty-first century (second edition). Peter Lang AG.

Kyle, D. W. (2011). Families' goals, school involvement, and children's academic achievement: A follow-up study thirteen years later. The School Community Journal, 21(2), 9-24.

McDonald, N. \& Fisher, D. (2006). Developing arts- loving readers. Rowman \& Littlefield Education: USA.

McLemore, W. P. (1976). Social studies strategies for today's learners. New York: MSS Information Corparation.

Mızrak Karc1, M. (2016). Öğrenci gözüyle ideal öğretmenin özellikleri: Gazi mesleki ve teknik Anadolu lisesi örneği. Milli Ĕgitim Dergisi, 209, 80-101.

Miles, M. B., \& Huberman, A.M. (1994). Qualitative data analysis: An expanded source book (2nd ed.). Thousand Oaks, CA: Sage. 
Milli Eğitim Bakanlığı (2018). Sosyal bilgiler dersi öğretim programı (İlkokul ve ortaokul 4,5,6 ve 7.siniflar). Ankara.

Moreira, J. S. (2002). Student perceptions of ideal teaching practices. A dissertation submitted to the faculty of the graduate school in partial fulfillment of the requirements for the degree of doctor of education. University of Pacific Stockton, California.

Murphy, K.P., Delli, L. A.M. \& Edwards, M. N. (2004). The ideal teacher and ideal teaching: Comparing beliefs of second-grade students, preservice teachers and inservice teachers. The Journal of Experimental Education, 72(2), 69-92.

NCSS (1994). National curriculum standarts for social studies: executive summary. https://www.socialstudies.org/standards/execsummary adresinden 07.04.2020 tarihinde alındi.

Nicholas, H. \& Williiams, A. (2010). School experience influences on pre-service teachers' evolving beliefs about effective teaching. Teaching and Teacher Education, 26(2), 278289. schly, D. J. (2007). Effective classroom management: Teacher preparation and professional development. https://files.eric.ed.gov/fulltext/ED543769.pdf adresinden $\underline{23.05 .2020}$ de alınd1.

Petty, T. M., Good, A. J. \& Handler, L. K. (2016). Impact on student learning: National Board Certified Teachers' perspectives. Education Policy Analysis Archives, 24 (49), 1-19.

Ross, E. W. (2006). The social curriculum. Purposes, problems and posibilities (third edt.). Albany: State University of New York Press.

Schug, M. C., Todd, R. J. \& Beery, R. (1982). Why kids don't like social studies. Paper presented at the Annual Meeting of the National Council for the Social Studies, Boston, MA.

Sezer, Ş. (2018). Öğretmenlerin sınıf yönetimi tutumlarının öğrencilerin gelişimi üzerindeki etkileri: fenomenolojik bir çözümleme. Hacettepe Üniversitesi Ĕgitim Fakültesi Dergisi, 33 (2), 534-549.

Shivakumar, G.S. \& Manichander, T. (2013). Restructuring the future classroom - A global perspective. Journal on School Educational Technology, 9(2), 19-24.

Sivakumar, R. (2018). Methods and resources in teaching social studies. Journal of Contemporary Educational Research and Innovations, 8 (2), 207-216.

Telli, S., Brok, P. \& Çakıroğlu, J. (2008). Öğretmen ve öğrencilerin ideal öğretmen hakkındaki görüşleri. Eğitim ve Bilim, 33(149), 118-129.

Yıldırım. A. \& Şimşek, H. (2013). Sosyal bilimlerde nitel araştırma yöntemleri (9. Baskı). Ankara: Seçkin Yayınları.

Yurdakal, İ. H. (2019). Ortaokul öğrencilerinin ideal öğretmen ve ideal öğretim süreçlerine yönelik görüşleri. III. Uluslararası Sinırsız Eğitim ve Araştırma Sempozyumu. USEAS 2019.

Zevin, J. (2009). Young citizens of the world-teaching elementary social studies through civic engagement. New York: Routledge. 